
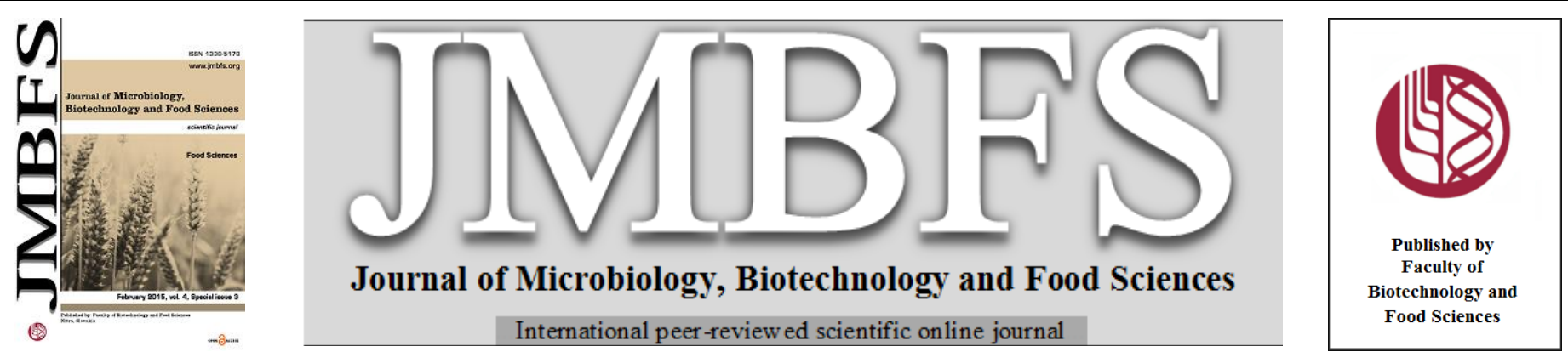

\title{
IMPACT OF SELECTED PARAMETERS ON MILK PRODUCTION IN TSIGAI BREED
}

\section{Martina Vršková ${ }^{* 1}$, Vladimír Tančin ${ }^{1,2}$, Katarína Kirchnerová ${ }^{1}$, Petr Sláma ${ }^{3}$}

\author{
Address(es): Ing. Martina Vršková, PhD. \\ ${ }^{1}$ National Agricultural and Food Centre, RIAP Nitra, Hlohovecká 2, 95141 Lužianky, Slovak Republic, 00421903546401. \\ ${ }^{2}$ Slovak University of Agriculture in Nitra, Trieda A. Hlinku 2, 94976 Nitra, Slovak Republic. \\ ${ }^{3}$ Mendel University Brno, Zemědelská 1, 61300 Brno, Czech Republic.
}

*Corresponding author: vrskova@ vuzv.sk

doi: $10.15414 /$ jmbfs.2015.4.special3.185-187

\section{ARTICLE INFO}

Received 29.11.2014

Revised 5. 12. 2014

Accepted 6. 12. 2014

Published 2. 2. 2015

$\frac{\overline{\text { Regular article }}}{\text { OPEN }{ }_{\text {Access }}}$

\begin{abstract}
The objective of our research was to study selected parameters which affect milk production. The study was performed in the selected herd of purebred T sigai ewes (231 animals). Regular milk yield recording was performed during the morning milking in around the middle of April, May and June. Milk samples were analyzed for basic milk composition (fat, protein and lactose) and somatic cells count. According to animals, the dairy ewes were divided into the four groups on the basis of individual $\operatorname{SCC}\left(\mathrm{G}_{1}=\mathrm{SCC}\right.$ $<100 \times 10^{3}$ cells.ml ${ }^{-1}, \mathrm{G}_{2}=\mathrm{SCC}$ bet ween $100-400 \times 10^{3}$ cells. $\mathrm{ml}^{-1}, \mathrm{G}_{3}=\mathrm{SCC}$ between $400-700 \times 10^{3}$ cells. $\mathrm{ml}^{-1}, \mathrm{G}_{4}=\mathrm{SCC}>10^{6}$ cells. $\mathrm{ml}^{-1}$ to study the frequency of distribution of animals in selected group of ewes throughout experimental period. We have not created group with SCC bet ween $700-1000 \times 10^{3}$ cells.ml ${ }^{-1}$ because there would not be sufficient number of animals. The average daily milk production in selected herd of T sigai was $614.51 \mathrm{ml}$, equivalent to 95.65 liters for a normalized lactation. We reached the highest daily milk production in April $779 \mathrm{ml}$ and the highest content of fat and protein in May, while milk production was lower by only $30 \mathrm{ml}$. We conclude that the protein content of milk was over $6 \%$ within each division, whether by order of lact ation, season or somatic cells count, except of June $(5.98 \%)$. We found a tendency to lower milk production by a higher SCC. With the increasing SCC decreased lactose
\end{abstract} content from $4.66 \%$ (G1) to $4.27 \%$ (G4) and there is a need for performing bacteriological examination in milk.

Keywords: Sheep, milk yield, milk composition, SCC

\section{INTRODUCTION}

Rearing small ruminants in Slovakia has a rich history. Nevertheless, the sector has always been marginal to the livestock sector. Sheep and goat production function in addition to the much greater importance of non-productive, as a factor positively affecting the environment and cultural character of rural, which is currently within the purview of sustainable agriculture and rural development particularly important (Margetín et al., 2013a). Ewe's milk is mainly used for making the cheese in Slovakia. Although the SCC is not considered as factor influencing the price of milk, it is also an important factor determining its yield and quality of the final product (Oravcová et al., 2007; Margetín et al., 2013b). Selection for milk yield, milk components and health of ewe's udder may have an impact on the further improvement of Slovakian breeds of local origin traditionally, i.e. Tsigai and Improved Valachian. In dairy cattle is standard practice detection of subclinical mastitis by milk somatic cell counts (SCC). In dairy ewe's instantaneous physiological and pathological thresholds of SCC ranging from $(0.25$ to 1.0$) \times 10^{6}$ cells $/ \mathrm{ml}$, have been available since the early 1990s (Ariznabarreta et al.,2002). In sheep and goats, mastitis episodes are the main reason for culling because of sanitary problems, which occur mainly during the first 2-3 months of lactation (Bergonier et al., 2003; Leitner et al., 2008). Before the milking of sheep rarely used suitable method for the detection of subclinical mastitis (NK test, California Mastitis Test - CMT, Whiteside Test WST), although their use is generally recommended (Bergonier et al., 2003; Špánik et al., 1996).

Berthelot et al. (2006) recommends that a decision rule proposes to consider an udder as healthy if every SCC are lower than $0.500 \times 10^{6}$ cells $/ \mathrm{ml}$ and infected if at least two individual SCC are higher than 1 or 1.2 million cells $/ \mathrm{ml}$. Arias et al. (2012) found by manchega sheep that milk yield was always higher for ewe with $\mathrm{SCC} \leq 300 \times 10^{3}$ cells $/ \mathrm{ml}$ than for those with $\mathrm{SCC}>300 \times 10^{3}$ cells $/ \mathrm{ml}$. Subclinical mastitis should be always suspected as one of the primary causes in cases of decreased milk production in dairy herds (Fragkou et al.,2014). In fact, coagulase-negative staphylococci, which are the most common aetiological agents of subclinical mastitis (Contreras et al., 2007), are also frequent inhabitants of the skin of the udder. Most sheep mastitis occurs before the end of lactation (at the beginning of dry period) and also during the rearing lambs (Albenzio et al., 2003; Bergonier et al., 2003; Contreras et al., 2007). The objective of our research was to study selected parameters which affect milk production in Tsigai breed in the year 2013 .

\section{MATERIAL AND METHODS}

The study was performed in the selected herd of purebred Tsigai ewes (231 animals). The ewes were machine milked twice daily after weaning of their lambs at the beginning of April. Regular milk yield recording was performed during the morning milking in around the middle of April, May and June. Individual milk samples were obtained from whole milk collection as an average sample. Milk samples from each udder were transported to the certificated Central laboratory of the Breeding Services of the Slovak Republic (Plemenárske služby š.p. Bratislava) for milk analysis. Milk samples were analyzed for basic milk composition (fat, protein and lactose) and somatic cells count (SCC). Basic milk composition was done by MilkoScan FT120 (Foss, Hillerød, Denmark) and somatic cells count were determined using a Fossomatic 90 instrument (Foss Electric, Hillerod, Denmark) after heat treatment at $40{ }^{\circ} \mathrm{C}$ for $15 \mathrm{~min}$. According to animals, the dairy ewes were divided into the four groups on the basis of individual SCC $\left(\mathrm{G}_{1}=\mathrm{SCC}<100 \times 10^{3}\right.$ cells. $\mathrm{ml}^{-1}, \mathrm{G}_{2}=\mathrm{SCC}$ between 100 $400 \times 10^{3}$ cells. $\mathrm{ml}^{-1}, \mathrm{G}_{3}=\mathrm{SCC}$ between $400-700 \times 10^{3}$ cells. $\mathrm{ml}^{-1}, \mathrm{G}_{4}=\mathrm{SCC}>10^{6}$ cells. $\mathrm{ml}^{-1}$ to study the frequency of distribution of animals in selected group of ewes throughout experimental period. We have not created group with SCC bet ween $700-1000 \times 10^{3}$ cells. $\mathrm{ml}^{-1}$ because there would not be sufficient number of animals. The frequency of distribution of ewes in different SCC sorting groups was also study depending on the parity (first and second), season (sampling 
periods - April, May, Jun) and milk yield and composition (fat, protein and lactose). Statistical analysis was done by SAS/ST AT 9.2 (PROC Mixed, 2009).

\section{RESULTS AND DISCUSSION}

The average daily milk production $614.51 \mathrm{ml}$ in selected herd of Tsigai was observed, which is equivalent to 95.65 liters for a normalized lact ation. The milk yield is by $20 \%$ lower than the breed standard specifies of Tsigai breed (ZCHOK, 2014). Dairy ewe's at $1^{\text {th }}$ lactation achieved $654.84 \mathrm{ml}$ of average daily milk production and the second one $574.18 \mathrm{ml}$. Although, the sheep of the $2^{\text {nd }}$ lactation had lower milk yield by $12 \%$, sheep reached a higher fat and protein (tab. 1). The lower fat content, but higher protein content compared to Oravcová et al. (2007) was observed. From the available publications Špánik et al. (1996),
Margetín. et al. (1998) and Oravcová et al. (2005), which researched the composition of Tsigai milk rearing in Slovakia, a positive trend of increasing milk production was observed. Comparison with our results the highest daily milk production in April $779 \mathrm{ml}$ was reached (tab. 2). Furthemore, the highest content of fat and protein in the month of May was observed, when the average daily milk production was lower (by $30 \mathrm{ml}$ ) compared to the April. It was found that the protein content of milk was over $6 \%$ within each division. Compared to Antonič et al. (2013) we reached in April increased daily milk yield and containing components, excluding lact ose $0.5 \%$ less. This situation could be explain with a higher content of somatic cells. The number of somatic cells was slowly reduced, what was probably due to an adaptation of sheep to the machine milking.

Table 1 The invest igated parameters depending on the order of lactation

\begin{tabular}{lcccr}
\hline & \multicolumn{4}{c}{ Lactation } \\
\hline & \multicolumn{2}{c}{ First $(\mathrm{n}=87)$} & \multicolumn{3}{c}{ Second $(\mathrm{n}=144)$} \\
\cline { 2 - 5 } Milk yield $(\mathrm{ml})$ & mean & S. E. & mean & S. E. \\
\cline { 2 - 5 } Fat $(\%)$ & 654.84 & 46.08 & 574.18 & 38.00 \\
Protein $(\%)$ & 7.69 & 0.15 & 7.78 & 0.13 \\
Lactose $(\%)$ & 6.00 & 0.07 & 6.21 & 0.06 \\
logSCC & 4.44 & 0.03 & 4.37 & 0.03 \\
\hline
\end{tabular}

SCC is used to assess the health status of the cows, sheep or goats udder. Among the group of sheep on the first and second lactation were observed minimal differences (tab. 1). Depending on the season, we found statistically significant differences bet ween April and June, and May and June (tab. 2). In April could be somatic cell count increased become of stress of weaning lambs, the start of machine milking and changing the microbial composition of the environment sheep put out to pasture.

Table 2 The invest igated parameters depending on the season

\begin{tabular}{llclcccc}
\hline & \multicolumn{9}{c}{ Season (months) } \\
\hline & \multicolumn{3}{c}{ April } & \multicolumn{3}{c}{ May } & \multicolumn{3}{c}{ June } \\
\cline { 2 - 8 } Milk yield (ml) & mean & S. E. & mean & S. E. & mean & S. E. & Significant \\
\cline { 2 - 8 } Fat (\%) & $779^{+++}$ & 88.00 & $749^{+++}$ & 88.00 & $547^{+++}$ & 85.00 & $1: 3,2: 3$ \\
Protein (\%) & $7.75^{+++}$ & 0.42 & $8.64^{+++}$ & 0.41 & $8.26^{+++}$ & 0.40 & $1: 2,1: 3$ \\
Lactose (\%) & $6.16^{+}$ & 0.14 & $6.17^{+}$ & 0.14 & $5.98^{+}$ & 0.14 & $1: 3,2: 3$ \\
logSCC & $4.47^{+++}$ & 0.08 & $4.32^{+++}$ & 0.08 & $4.56^{+++}$ & 0.08 & $1: 2,2: 3$ \\
\hline+++ significant $\mathrm{P}<0.0001 ;+$ significant P<0.05 & $5.51^{+++}$ & 0.21 & $5.48^{+++}$ & 0.21 & $4.79^{+++}$ & 0.20 & $1: 3,2: 3$ \\
\hline
\end{tabular}

In Table 3, the animals were divided into groups according to SCC. It was found a tendency to lower milk production by a higher SCC. With the increasing SCC lactose content decreased from $4.66 \%$ (G1) to $4.27 \%$ (G4). This phen omenon was also statistically significant. Reduced lactose content refers to the occurrence of mastitis. For individual animals, the best approach has been provided by Berthelot et al. (2006). The mentioned author suggested that values $<0.5 \times 10^{6}$ cells $\mathrm{ml}^{-1}$ indicate a healthy mammary gland and values $>1.0 \times 10^{6} \mathrm{cells} \mathrm{m}^{-1}$ indicate a mammary gland with clinical or subclinical mastitis. Furthermore, here is no need to perform a simultaneous bacteriological examination of milk samples to confirm the problem. Values between $0.5 \times 10^{6}$ and $1.0 \times 10^{6}$ cells $\mathrm{ml}^{-1}$, according to those authors, indicate 'suspected disease', hence there is a need for performing bacteriological examination in milk.

Table 3 The milk yield and milk composition by SCC

\begin{tabular}{|c|c|c|c|c|c|c|c|c|}
\hline & \multicolumn{8}{|c|}{ SCC group } \\
\hline & \multicolumn{2}{|c|}{$\mathbf{G}_{1}(1), \mathrm{n}=81$} & \multicolumn{2}{|c|}{$\mathbf{G}_{2}(2), \mathrm{n}=100$} & \multicolumn{2}{|c|}{$\mathbf{G} 3(3), n=21$} & \multicolumn{2}{|c|}{$\mathbf{G}_{4}(4), n=29$} \\
\hline & mean & S. E. & mean & S. E. & mean & S. E. & mean & S. E. \\
\hline Milk yield (ml) & 744 & 90 & 754 & 84 & 593 & 96 & 674 & 96 \\
\hline Fat $(\%)$ & 7.68 & 0.42 & 8.00 & 0.39 & 8.13 & 0.46 & 7.71 & 0.46 \\
\hline Protein $(\%)$ & 6.03 & 0.15 & 6.05 & 0.14 & 6.14 & 0.16 & 6.19 & 0.16 \\
\hline Lactose (\%) & $4.66^{+++}$ & 0.08 & $4.50^{+++}$ & 0.08 & $4.38^{+++}$ & 0.09 & $4.27^{+++}$ & 0.09 \\
\hline
\end{tabular}

$\mathrm{G}_{1}=$ Group $_{1}$ of $\left(\mathrm{SCC}<100 \times 10^{3}\right.$ cells.ml $\left.{ }^{-1}\right), \mathrm{G}_{2}=\left(\right.$ SCC bet ween $100-400 \times 10^{3}$ cells.ml $\left.{ }^{-1}\right), \mathrm{G}_{3}=\left(\mathrm{SCC}\right.$ bet ween $400-700 \times 10^{5}$ cells.ml ${ }^{-1}$ and $\mathrm{G}_{4}=$ $\left(\mathrm{SCC}>10^{6}\right.$ cells. $\mathrm{ml}^{-1}$ ), Significant $\mathrm{P}<0.0001$ between $1: 2,1: 3,1: 4,2: 4$.

\section{CONCLUSION}

From this herd of purebred Tsigai was $78 \%$ of ewes below SCC $400 \times 10^{3}$ cells. $\mathrm{ml}^{-1}$. This SCC indicated good health status of experimental ewes, at which $62 \%$ sheep were at the second lactation. Although the average daily milk production was $614.51 \mathrm{ml}$, equivalent to $95.65 \mathrm{l}$ for a normalized lactation, reached above the average content of protein (above $6.0 \%$ ). We found a tendency to lower milk production by a higher SCC. With the increasing SCC decreased lact ose content from $4.66 \%$ (G1) to $4.27 \%$ (G4). Reduced lactose content refers to the occurrence of mastitis and there is a need for performing bacteriological examination in milk. However more detail study is needed to see relationship bet ween high SCC and presence of microorganisms to better understanding the reasons the physiological and pathological SCC in the udder.

Acknowledgments: This article was written during realization of the project "MLIEKO č. 262202201 96"supported by the Operational Programme Research and Development funded from the European Regional Development Fund. 


\section{REFERENCES}

ALBENZIO M., TAIBI L., CAROPRESE M., DE ROSA G., MUSCIO A., SEVI A. 2003. Immune response, udder health and productive traits of machine milked and suckling ewes, Small Rumin. Res. 48: 189-200. http://dx.doi.org/10.1016/s0921-4488(03)00005-1

ANT ONIČ, J., JACKULIAKOVÁ, L., UHRINČAŤ, M., MAČUHOVÁ, L., ORAVCOVÁ, M., T ANČIN, V. 2013. Changes in milk yield and composition after lamb weaning and st art of machine milking in dairy ewes. Slovak Journal of Animal Science, 46(3), 93-99.

ARIAS, R., OLIETE, B., RAM, M., ARIAS, C., GALLEGO, R., MONTORO, V., GONZALO, C. AND EZ-GUZM, M. D. P. 2012. Long-term study of environmental effects on test-day somatic cell count and milk yield in Manchega sheep. Small Ruminant Research, 106(2-3), 92-97. http://dx.doi.org/10.1016/j.smallrumres.2012.03.019

ARIZNABARRETA, A., GONZALO, C., SAN PRIMITIVO, F. 2002. Microbiological quality and somatic cell count of ewe milk with special reference to staphylococci. J. Dairy Sci. 85, 1370-1375. http://dx.doi.org/10.3168/jds.s0022-0302(02)74203-3

BERGONIER, D., DE CRÉMOUX, R., RUPP, R., LAGRIFFOUL, G., BERT HELOT, X. 2003. Mastitis of dairy small ruminants. Veterinary Research 34, 689-716. http://dx.doi.org/10.1051/vetres:2003030

BERTHELOT X., LAGRIFFOUL, G., CONCORDET, D., BARILETT, F., BERGONIER. D. 2006. Phy siological and pathological thresholds of somatic cell counts in ewe milk. Small Ruminant Research, 62(1-2), 27-31. http://dx.doi:10.1016/j.smallrumres.2005.07.047

CONTRERAS, A., SIERRA, D., SANCHEZ, A., CORRALES, J.C., MARCO, J.C., PAAPE, M.J.GONZALO, C. 2007. Mastitis in small ruminants. Small Rumin. Res. 68,145-153. http://dx.doi: 10.1016/j.smallrumres.2006.09.011 FRAGKOU I.A., BOSCOS C.M, FTHENAKIS, G.C. 2014. Diagnosis of clinical or subclinical mastitis in ewes. Small Ruminant Research, 118, 86-92. http://dx.doi.org/10.1016/j.smallrumres.2013.12.015
LEIT NER, G., SILANIKOVE, N., MERIN, U. 2008. Estimate of milk and curd yield loss of sheep and goats with intrammamary infection and its relation to somatic cell count. Small Ruminant Research 74, 221-225. http://dx.doi: 10.1016/j.smallrumres.2007.02.009

MARGET ÍN M., HLAVATÝ, Š., PŘIBYL, J. 1998: Effect of genetic and nongenetic factors on milk composition in ewes of Improved Valachin and Tsigai breeds. J. Farm Anim. Sci., XXXI, 29-36.

MARGETÍN, M., MILERSKI, M., APOLEN, D., ČAPISTRÁK, A., ORAVCOVÁ, M., DEBRECÉNI, O. 2013a: Relationships between production, quality of milk and udder health status of ewes during machine milking. Journal of Central European Agriculture, 14(1), 328-340. http://dx.doi: 10.5513/JCEA01/14.1.1203

MARGETÍN, M. et al. 2013b. Chov oviec. In Chov zvierat v marginálnych oblastiach. 1. vyd. Nitra: CVŽV Nitra, 2013. Kapitola 3, s. 69-91. ISBN 978-8089418-26-8

ORAVCOVA M., GROENEVELD E., KOVAČ M., PEŠKOVIČOVA D., MARGETIN M. (2005): Estimation of genetic and environmental parameters of milk production traits in Slovak purebred sheep using test-day model. Small Rumin. Res., 56, 113-120. http://dx.doi: 10.1016/j.smallrumres.2004.03.002 ORAVCOVÁ M., MARGETIN, M., PEŠKOVIČOVÁ, D., DAŇO, J., MILERSKI, M., HETÉNYI, L., POLÁK, P.2007: Factors affecting ewe's milk fat and protein content and relationships between milk yield and milk components. Czech Journal of Animal Science, 52(7), 189-198.

ŠPANIK, J., KAČINCOVA, A., MARGETIN, M., ČAPISTRAK, A., KALIŠ M. (1996): Dependence of sheep milk quality on somatic cell counts. Farm Anim. Sci., 29, 111-116.

ZCHOK. 2014. Šlachtitel'ský program plemena cigája. www.zchok.sk 